\title{
Faktor yang Memengaruhi Kemandirian Ekonomi Pesantren (Studi Pesantren Al-Ittifaq Bandung)
}

\author{
Determinants of Economic Independence of the Islamic Boarding School (Study of \\ the Bandung Al-Ittifaq Boarding School)
}

\author{
Maya Silvana ${ }^{1}$, Deni Lubis ${ }^{2}$ \\ ${ }^{1}$ Fakultas Ekonomi dan Manajemen, Institut Pertanian Bogor, Jalan Raya Dramaga, Bogor 16680, \\ Indonesia, mayasilvana01@gmail.com \\ ${ }^{2}$ Fakultas Ekonomi dan Manajemen, Institut Pertanian Bogor, Jalan Raya Dramaga, Bogor 16680, \\ Indonesia,denilubis@gmail.com
}

\begin{abstract}
Islamic boarding school has the potential to develop the Islamic economy through the Islamic boarding school business unit. Optimizing business units can create Islamic boarding school economic independence. Even so, the fact is that there are still many Islamic boarding school that have not utilized their potential. One of the Islamic boarding school that has succeeded in achieving economic independence through business units is the Al-Ittifaq Boarding School in Bandung. The aim of this research is to analyze economic activities and factors that influence the economic independence of the Al-Ittifaq Islamic Boarding School. Using Analytical Network Process (ANP), the factors that influence the economic independence of the Al-Ittifaq Islamic Boarding School are divided into four aspects, namely institutional, production, stakeholder, and market aspects. The results show that market aspect has the biggest impact affecting the economic independence in Al-Ittifaq Islamic Boarding School and the four most influential factors are the kiai leadership and management, production information systems, capital, and market availability.
\end{abstract}

Keywords: ANP, market aspects, Islamic boarding school economic independence, Al-Ittifaq Islamic Boarding School.

\begin{abstract}
Abstrak. Pesantren memiliki potensi dalam mengembangkan ekonomi syariah melalui unit usaha pesantren. Pengoptimalan unit usaha dapat menciptakan kemandirian ekonomi pesantren. Meskipun demikian, faktanya masih banyak pesantren yang belum memanfaatkan potensinya. Pesantren yang berhasil mencapai kemandirian ekonomi melalui unit usaha agribisnis adalah Pesantren Al-Ittifaq Bandung. Penelitian ini bertujuan untuk mengidentifikasi kegiatan ekonomi dan faktor yang memengaruhi kemandirian ekonomi Pesantren Al-Ittifaq. Dengan menggunakan metode Analytical Network Process (ANP), faktor yang memengaruhi kemandirian ekonomi pesantren Al-Ittifaq dibagi menjadi empat aspek, yaitu aspek kelembagaan, produksi, stakeholder, dan pasar. Hasil prioritas menunjukan bahwa aspek pasar memiliki pengaruh paling besar terhadap kemandirian ekonomi Pesantren Al-Ittifaq dan empat faktor yang paling berpengaruh adalah kepemimpinan kiai dan pengurus, sistem informasi produksi, permodalan, dan ketersediaan pasar.
\end{abstract}

Kata kunci: ANP, aspek pasar, kemandirian ekonomi pesantren, Pesantren Al-Ittifaq.

\section{PENDAHULUAN}

Kemiskinan merupakan permasalahan yang umum dihadapi negara berkembang seperti Indonesia. Perumusan dan implementasi kebijakan untuk mengentaskan kemiskinan dianggap masih kurang efektif karena hanya berfokus pada sektor ekonomi (Suryawati, 2010) Pengembangan berbagai sektor yang berkaitan perlu dilakukan, salah satunya adalah sektor pendidikan penelitian (Ranis dan Stewart, 2005) bahwa melalui pendidikan, seseorang dapat meningkatkan kapasitas diri, kreativitas dan produktivitas sehingga perekonomian dapat meningkat dalam jangka panjang. Pesantren memiliki peran dalam mengatasi hal tersebut sebagai salah satu lembaga pendidikan dalam menghasilkan sumber daya manusia yang berkualitas untuk menurunkan tingkat kemiskinan di Indonesia. Fakta menunjukkan bahwa dari tahun ke tahun jumlah pesantren dan santri di Indonesia cukup berkembang. 
Pada tahun 2018, terdapat 28,194 pesantren, dan 4,048,720 santri yang berada di bawah naungan pesantren. Jumlah santri tersebut mencapai $8.93 \%$ dari total 45,299,800 anak bersekolah di Indonesia (Badan Pusat Statistik, 2018).

Tabel 1 Perkembangan jumlah pesantren dan santri di Indonesia

\begin{tabular}{ccc}
\hline Tahun & Jumlah pesantren & Jumlah santri \\
\hline $2010-2011$ & 27,218 & $3,642,738$ \\
$2012-2013$ & 27,230 & $3,004,807$ \\
$2014-2015$ & 27,290 & $3,654,096$ \\
$2015-2016$ & 28,984 & $4,290,626$ \\
$2017-2018$ & 28,194 & $4,048,720$ \\
\hline
\end{tabular}

Sumber: Kementrian Agama, 2019.

Pesantren dapat mendukung pembangunan sumber daya manusia dengan memberikan keahlian wirausaha pada santri. Pesantren berpotensi mengembangkan ekonomi syariah untuk mencapai kemandirian ekonomi umat, sehingga pesantren turut berperan dalam pembangunan bangsa dan mengentaskan kemiskinan. Hal ini sejalan dengan sebuah penelitian (Isti'anah dan Sutikno, 2018) bahwa pemberdayaan ekonomi yang dilakukan Pesantren An-Nuqayah berhasil meningkatkan perekonomian masyarakat.

Komite Nasional Ekonomi dan Keuangan Syariah (KNEKS) menempatkan pesantren sebagai stakeholder yang memiliki potensi besar dalam pengembangan ekonomi syariah, khususnya industri halal. Kegiatan unit usaha pesantren di sektor produk halal dan penyediaan jasa layanan keuangan syariah, dapat bermafaat bagi kesejahteraan pesantren dan masyarakat sekitar (Suharto dan Fasa, 2018). Pernyataan tersebut sejalan dengan Masterplan Ekonomi Syariah Indonesia 2019-2024 yang diterbitkan oleh Kementerian Perencanaan Pembangunan Nasional/Badan Perencanaan Pembangunan Nasional (2018) bahwa pesantren turut berperan dalam halal value chain nasional. Unit usaha pesantren menjadi salah satu input industri halal nasional yang dapat mendukung kemandirian ekonomi pesantren dan secara aktif membangun sumber daya manusia industri halal di Indonesia.

Potensi pesantren sebagai salah satu pusat ekonomi syariah di Indonesia perlu untuk diberdayakan. Menurut data Kementerian Agama tahun 2004, baru terdapat 1,529 pesantren yang mengembangkan usaha bidang agribisnis, 404 pesantren bidang perindustrian, 111 pesantren bidang perdagangan, dan 41 pesantren mengembangkan bidang ekonomi kelautan dan perikanan (Tim Pekapontren, 2004). Jumlah tersebut hanya sekitar $0.96 \%$ dari total 21,521 pesantren yang ada di Indonesia saat itu. Pada tahun 2019, Kementrian Agama mempublikasikan data potensi ekonomi pesantren di Indonesia. Data tersebut menunjukkan bahwa terdapat 9008 pesantren yang berpotensi mendirikan unit usaha. Jumlah tersebut sekitar $32 \%$ dari total 27,722 pesantren di Indonesia.

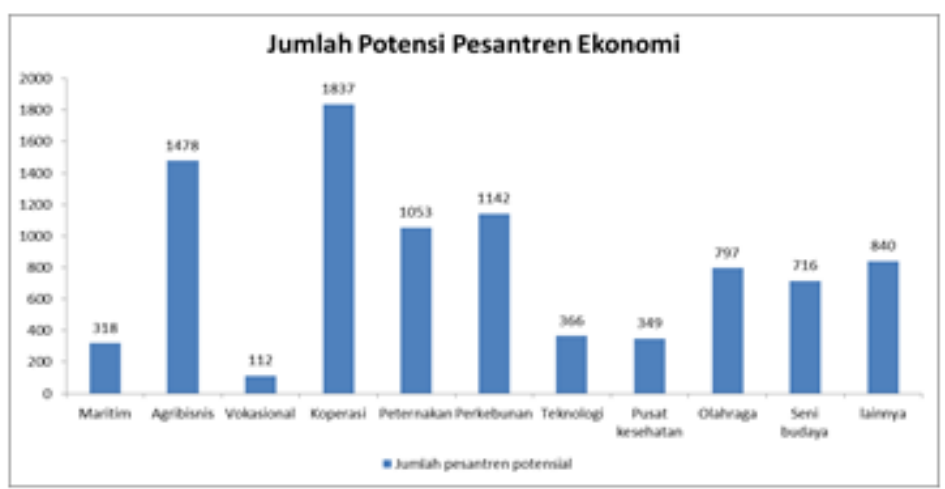

Sumber: Direktorat Pendidikan Pondok Pesantren Kementrian Agama, 2019.

Gambar 1 Jumlah potensi pesantren ekonomi 
Dari data di atas, dapat disimpulkan bahwa potensi ekonomi pesantren di Indonesia masih perlu dioptimalkan. Pengoptimalan unit usaha pesantren dalam jangka panjang dapat menciptakan kemandirian ekonomi pesantren, sehingga dalam pengelolaannya pesantren tidak lagi bergantung pada iuran santri maupun bantuan pihak lain. Meski masih terbatas, saat ini pengembangan unit usaha pesantren telah terjadi secara sporadis di beberapa pesantren, terutama pesantren yang memiliki endowment factor cukup besar dalam bentuk aset dan jumlah santri lulusan (Bank Indonesia, 2016).

Salah satunya adalah Pesantren Al-Ittifaq Bandung yang berhasil mencapai kemandirian ekonomi melalui unit usaha agribisnis. Pesantren Al-Ittifaq mampu memadukan antara kegiatan keagamaan dengan kegiatan usaha agribisnis. Seluruh kegiatan unit usaha Pesantren Al-Ittifaq melibatkan partisipasi langsung santri dan masyarakat sekitar pesantren. Pesantren Al-Ittifaq dibantu kelompok tani mampu menyediakan supply produk agribisnis secara kontinu untuk dipasarkan ke berbagai pasar modern dan tradisional di wilayah Bandung dan Jakarta. Hasil unit usaha digunakan untuk kegiatan operasional unit usaha, operasional pesantren dan kesejahteraan masyarakat.

Keberhasilan unit usaha pesantren Al-Ittifaq sudah diakui secara luas dan telah meraih berbagai penghargaan. Pada tahun 2019, Pesantren Al-Ittifaq menjadi tuan rumah kegiatan OPOP (One Pesantren One Product) yang diadakan oleh pemerintah daerah provinsi Jawa Barat. Pemilihan ini karena Pesantren Al-Ittifaq dinilai berhasil dalam membangun kemandirian pesantren melalui pemberdayaan ekonomi rakyat yang menjadi tujuan program OPOP. Saat ini, Pesantren Al-Ittifaq sudah memiliki lebih dari 20 pesantren binaan yang tersebar di seluruh Indonesia. Berdasarkan uraian di atas, Pesantren Al-Ittifaq dapat dijadikan percontohan pesantren yang mencapai kemandirian ekonomi melalui unit usaha pesantren. Sehingga diperlukan studi yang dapat memberikan gambaran pengelolaan unit usaha Pesantren Al-Ittifaq serta faktor yang memengaruhi kemandirian ekonomi Pesantren Al-Ittifaq agar dapat dijadikan sebagai referensi, khususnya bagi pesantren yang memiliki endowment factor yang sama untuk mengembangkan unit usaha pesantren.

\section{TINJAUAN PUSTAKA}

Pesantren merupakan lembaga pendidikan Islam yang menekankan pentingnya moral agama Islam sebagai pedoman hidup untuk dipahami, dihayati dan diamalkan dalam kehidupan sehari-hari. Pesantren memiliki fungsi sebagai lembaga pendidikan, sosial dan keagamaan. Pesantren merupakan salah satu sebuah bentuk nyata pemerintah dalam upayanya membentuk karakter unggul, sejalan dengan peraturan yang telah ditetapkan pada Peraturan Presiden No. 87 Tahun 2017 tentang Penguatan Pendidikan Karakter (Supriyanto, 2020).

Pesantren di Indonesia terbagi menjadi dua model yaitu pesantren salafiyah dan pesantren modern. Pada pesantren salafiyah metode pembelajaran dilakukan dengan kiai dan ustaz menggunakan kitab kuning sebagai media pembelajarannya, sedangkan pesantren modern sudah menggunakan kurikulum nasional yang mana santri tidak hanya mempelajari kitab saja, namun juga dengan pendekatan modern yang menggunakan satuan pendidikan formal, baik madrasah maupun sekolah umum dengan sistem pembelajaran berjenjang berdasarkan satuan waktu, seperti catur wulan, semester, tahun atau kelas (Sudarmo, 2021).

Secara umum, sumber keuangan pesantren berasal dari iuran pendidikan siswa (tuition and fees), bantuan pemerintah, unit usaha pesantren, zakat, wakaf dan infak lainnya. Namun pandangan tersebut dapat disanggah apabila pesantren mampu mencapai kemandirian pada sektor ekonomi itu sendiri. Kemandirian ekonomi pesantren adalah kemampuan pesantren untuk mengatur operasional pesantren melalui kegiatan ekonomi tanpa bergantung pada pihak lain. Salah satu indikator sebuah pesantren memiliki kemandirian ekonomi adalah hasil unit usaha memiliki kontribusi yang signifikan terhadap kegiatan edukasi dan operasional di pesantren sehingga kesinambungan pesantren tidak terlalu tergantung pada kontribusi uang partisipasi dari santri dan bantuan pihak lain (Bank Indonesia, 2015). 
Langkah terbaik untuk mencapai kemandirian ekonomi pesantren adalah dengan mendirikan unit usaha pesantren. Jenis-jenis unit usaha yang dapat dikembangkan pesantren umumnya diklasifikasikan ke dalam empat kelompok besar, yaitu: agribisnis (pertanian, perikanan, perkebunan), jasa (percetakan, Lembaga Amil Zakat, Baitul Maal wa Tamwil, koperasi), perdagangan (ritel, pertokoan, agen penjualan), dan industri (penjernihan air, mebel).

Ismanto dan Nasrullah (2019) melakukan penelitian mengenai dampak kehadiran unit usaha Pesantren Walindo. Hasil penelitian menunjukan bahwa pemimpin pesantren berperan besar dalam mendirikan dan mengembangkan unit usaha Pesantren Walindo. Keberadaan unit usaha pesantren memiliki hubungan positif dengan perkembangan dan kemandirian ekonomi Pesantren Walindo. Unit usaha pesantren yang berkembang memberikan dampak positif terhadap aspek ekonomi, pendidikan, dan sosial pesantren. Beberapa faktor yang berperan dalam pengembangan unit usaha Pesantren Walindo adalah pemimpin pesantren, partisipasi santri, kerja sama antara pesantren dan masyarakat.

Menurut Marlina dalam Yaqin et al. (2021), dengan sumber daya yang dimililiki, pesantren memiliki potensi besar untuk mengembangkan ekonomi syariah di Indonesia. Pesantren dianggap sebagai lembaga pengkaderan ulama dan dai yang diakui masyarakat. Potensi yang dimiliki oleh pesantren dalam mengembangkan ekonomi syariah mencakup tiga hal yaitu pesantren sebagai agen perubahan sosial di bidang ekonomi syariah, pesantren sebagai laboratorium bisnis syariah dan pesantren sebagai pusat belajar ekonomi syariah.

Hal ini sejalan dengan penelitian Annisa (2019) mengenai hubungan Koperasi Pondok Pesantren (Kopontren) dengan ekosistem halal value chain. Pesantren memiliki sumber daya manusia yang berpotensi untuk mengembangkan perekonomian pesantren yang dapat berdampak positif untuk perekonomian nasional. Hasil penelitian menunjukkan bahwa kehadiran koperasi pondok pesantren sebagai penggerak perekonomian pesantren berpengaruh secara signifikan dalam menghidupkan halal value chain (rantai nilai halal) pada setiap bagian lingkungan ekosistem pondok pesantren dengan menerapkan nilai-nilai halal dalam aktivitas produksi, distribusi hingga aktivitas konsumsi anggotanya baik berupa barang ataupun jasa.

Arifin dalam Ryandono (2018) melakukan penelitian bahwa berkembangnya unit usaha Pesantren AlIttifaq tidak lepas dari peran pengurus pesantren, partisipasi masyarakat dan pihak eksternal pesantren seperti pemerintah, Bank Indonesia dan berbagai instansi lainnya. Pihak internal dan eksternal Pesantren Al-Ittifaq secara aktif memberikan program sosial, permodalan, bimbingan teknis, dan pelatihan untuk meningkatkan kualitas hidup masyarakat.

Terdapat empat aspek manajerial yang perlu diperhatikan untuk menunjang kesuksesan unit usaha pesantren, yaitu aspek produksi, pemasaran, keuangan, dan pengelolaan sumber daya insani (Bank Indonesia, 2016). Lembaga pesantren sebaiknya memiliki aspek operasi yang efektif untuk diimplementasikan sehingga setiap kegiatan produksi maupun pelaporannya dapat dilakukan dengan efektif dan efisien.

Penelitian Rahmadani dan Makmur (2019) menunjukan pentingnya aspek produksi dan ketersediaan standar operasional pada unit usaha. Hal ini digunakan sebagai acuan penjualan produksi untuk menunjang kesuksesan unit usaha dari segi sumber daya, inovasi, pengelolahan, cita rasa makanan, dan kualitas mesin produksi. Lembaga pesantren seharusnya memiliki standar produksi yang efektif untuk diimplementasikan sehingga setiap kegiatan produksi maupun pelaporannya dapat dilakukan dengan efektif. Pada aspek pemasaran, unit bisnis pesantren harus memiliki bauran kebijakan pemasaran yang baik sehingga dapat bertahan menghadapi kompetisi dengan pesaing-pesaingnya. Aspek pemasaran adalah sebuah strategi yang disusun untuk mencapai target pasar serta tujuan unit usaha, dari segi penentuan harga, promosi, distribusi, dan kepuasan konsumen. 
Pada aspek keuangan, transparansi dalam pembuatan laporan keuangan yang standar dipahami secara formal akan memudahkan akses pesantren ke pasar. Fahmi dalam Rahmadani dan Makmur (2019) menyatakan bahwa aspek keuangan berperan penting untuk menganalisis seberapa besar biaya yang akan dikeluarkan dan rincian penggunaan dana. Selain itu dalam pembuatan laporan keuangan yang standar dipahami secara formal akan memudahkan akses pesantren ke pasar. Metode transparansi pada aspek keuangan juga berpotensi memiliki pengaruh besar.

Hal tersebut didukung oleh hasil penelitian Umar dan Syawalina (2018) mengenai pengaruh transparansi pengelolaan keuangan daerah terhadap kinerja instansi inspektorat Aceh. Transparansi berpengaruh dalam peningkatan kualitas kinerja. Dari aspek pengelolaan sumber daya insani, lembaga pesantren harus memiliki merit system yang memadai agar cukup kompetitif dalam bersaing dengan lembaga pendidikan lain dalam hal menarik pengelola unit usaha yang memiliki komitmen dan kualitas tinggi. Hal ini sejalan dengan penelitian Melis (2019) yang menyatakan bahwa perkembangan zaman menjadi urgensi kebutuhan sumber daya manusia yang berkualitas.

Selain aspek yang menunjang kesuksesan unit usaha pesantren, terdapat empat aspek yang menghambat pengembangan kemandirian ekonomi pesantren, yaitu dalam aspek pemasaran, jaringan, kapabilitas, dan permodalan (Bank Indonesia, 2019). Dalam aspek pemasaran yaitu terbatasnya akses pasar untuk menjual hasil produksi pesantren. Dalam aspek jaringan yaitu keterbatasan networking baik sisi supply maupun demand. Dalam aspek kapabilitas yaitu keterbatasan kapabilitas untuk meningkatkan kapasitas ekonomi. Dalam aspek permodalan yaitu keterbatasan permodalan sendiri dan akses ke lembaga keuangan. Bauran strategi pemasaran tersebut meliputi pengembangan produk, strategi harga, strategi distribusi, dan promosi.

\section{METODE}

Penelitian ini dilakukan di Pesantren Al-Ittifaq yang berlokasi di Bandung, Jawa Barat sejak bulan Desember 2019. Pemilihan lokasi dilakukan secara purposive (kriteria tertentu) dengan pertimbangan responden adalah orang yang terlibat langsung atau pakar yang paham dengan pegelolaan kegiatan ekonomi pesantren Al-Ittifaq. Responden dalam penelitian ini berjumlah tujuh orang yaitu, pengurus Koperasi Pondok Pesantren Al-Ittifaq, pengurus PT Al-Ittifaq Agriculture Indonesia, pengurus peternakan Al-Ittifaq, anggota Koperasi Pondok Pesantren Al-Ittifaq, Departemen Ekonomi Syariah Bank Indonesia (DEKS BI), Majelis Ulama Indonesia (MUI) regional Bandung, dan Kepala Desa Alamendah.

Jenis data yang digunakan dalam penelitian ini terdiri dari data primer dan data sekunder. Data primer diperoleh dari wawancara mendalam (in-depth interview) kepada para pakar dan praktisi yang memiliki pemahaman mendalam. Penelitian dilanjutkan dengan pengisian kuesioner kepada responden pada pertemuan selanjutnya. Data sekunder diperoleh dari dokumen Pesantren Al-Ittifaq, Badan Pusat Statistik, Kementerian Agama, Bank Indonesia, buku, jurnal terkait, serta sumber lainnya yang dapat membantu ketersediaan data.

\section{Analytic Network Process (ANP)}

Penelitian ini menggunakan metode ANP (Analytic Network Process). Output metode ini yaitu terciptanya kerangka kerja yang dapat mengatasi permasalahan pengambilan keputusan. Metode ini digunakan dalam bentuk penyelesaian dengan pertimbangan atas penyesuaian kompleksitas masalah secara penguraian sintesis disertai adanya skala prioritas yang menghasilkan pengaruh prioritas terbesar. ANP menggunakan network tanpa penjelasan yang spesifik tentang level-level yang ada seperti pada suatu hirarki. Saling memberikan timbal balik pada tiap elemen merupakan konsep inti dari ANP (Romindo dan Jamaludin, 2019). 


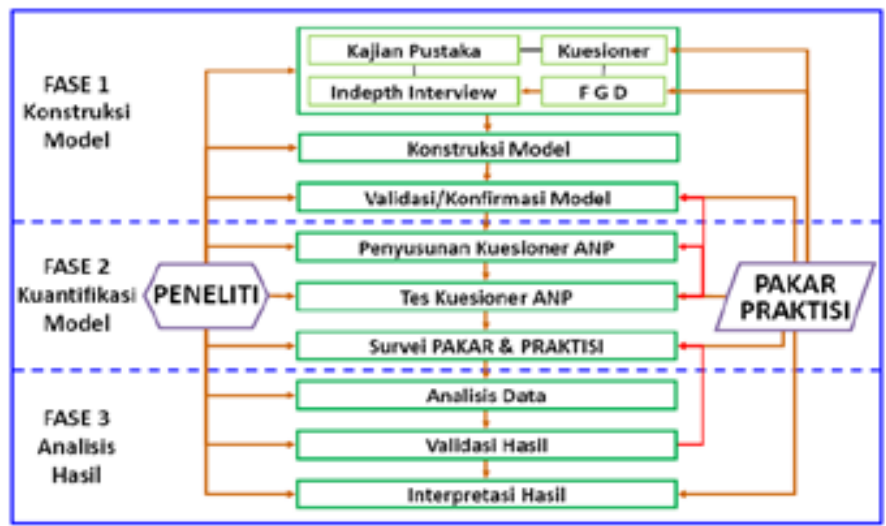

Sumber: Ascarya, 2011.

Gambar 2 Alur ANP

\section{Konstruksi model}

Konstruksi model ANP disusun berdasarkan literature review secara teori maupun empiris dan memberikan pertanyaan pada pakar dan praktisi melalui wawancara untuk mengkaji informasi secara lebih dalam untuk memperoleh permasalahan yang sebenarnya. Sebuah penelitian menggunakan metode ANP untuk menentukan alternatif pilihan strategi mitigasi risko kecelakaan kerja di sebuah PT. Hasil penelitian mengatakan bahwa terdapat keteraitan antara kriteria-kriteria, subkriteriasubkriteria dan alternatif yang yang memiliki hubungan ketergantungan dalam pemilihan dan penentuan penyebab terjadinya kecelakaan kerja (Fitri et al., 2020). Metode ANP juga digunakan pada penelitian Romindo dan Jamaludin (2019) untuk menentukan keputusan pemilihan toko daring yang terbaik di lingkungan Politeknik Ganesha.

\section{Kuantifikasi model}

Kuantifikasi model menggunakan pertanyaan dalam kuesioner ANP berupa pairwise comparison (pembandingan pasangan antar elemen dalam cluster) untuk mengetahui yang lebih besar pengaruhnya (lebih dominan) di antara keduanya dan seberapa besar perbedaannya melalui skala numerik 1-9. Data hasil penilaian kemudian dikumpulkan dan dimasukkan melalui software Super Decisions untuk diproses sehingga menghasilkan output berbentuk prioritas dan supermatriks. Hasil dari setiap responden akan dimasukkan pada jaringan ANP tersendiri (Firmansyah et al., 2021).

Tabel 2 Perbandingan skala verbal dan skala numerik

\begin{tabular}{lc}
\hline \multicolumn{1}{c}{ Skala Verbal } & $\begin{array}{c}\text { Skala } \\
\text { Numerik }\end{array}$ \\
\hline \multirow{2}{*}{ Amat sangat lebih besar pengaruhnya } & 9 \\
\cline { 2 - 2 } Sangat lebih besar pengaruhnya & 8 \\
\cline { 2 - 2 } Lebih besar pengaruhnya & 7 \\
\hline \multirow{2}{*}{ Sedikit lebih besar pengaruhnya } & 6 \\
\hline Sama besar pengaruhnya & 5 \\
\hline Sumber: Ascarya (2005) & 2 \\
\hline
\end{tabular}

\section{Sintesis dan analisis}

Analisis hasil dengan melakukan input hasil kuesioner yang telah diisi oleh responden pada software Super Decisions, lalu mencari nilai geometric mean (GMk) dan menghitung nilai Kendal"s coefficient 
of concordance yang merupakan alat ukur untuk menghitung rater agreementt dengan menggunakan microsoft excel.

a. Geometric mean

Berdasarkan penelitian yang dilakukan oleh Saaty dan Vargas dalam Firmansyah et al. (2021), geometric mean digunakan untuk mengetahui hasil penilaian individu dari para responden dan menentukan hasil pendapat pada satu kelompok. Geometric mean merupakan jenis penghitungan rata-rata yang menunjukan tendensi atau nilai tertentu dimana memiliki formula sebagai berikut:

$$
\left(\prod_{1}^{n}=1 \propto_{1}\right)^{1 \text { in }}=\sqrt[n]{a_{1} a_{2} \ldots a_{n}}
$$

\section{b. Rater Agreement}

Berdasarkan perhitungan yang dilakukan oleh Ascarya dalam Firmansyah et al. (2021), rater agreement adalah ukuran yang menunjukan tingkat kesesuaian (persetujuan) para responden $\left(\mathrm{R}_{1}-\mathrm{R}_{\mathrm{n}}\right)$ terhadap suatu masalah dalam satu cluster. Adapun alat yang digunakan untuk mengukur rater agreement adalah Kendall's coefficient of concordance (W; $0<\mathrm{W} \leq 1)$. W=1 menunjukan kesesuaian yang sempurna. Langkah menghitung Kendall's (W), yang pertama adalah dengan memberikan ranking pada setiap jawaban kemudian menjumlahkannya.

$$
\mathrm{R} 1=\sum_{m}^{j}-=1_{r, j}
$$

Nilai rata-rata dari total ranking adalah:

$$
\mathrm{R}={ }^{\frac{1}{2}} \mathrm{~m}(\mathrm{n}+1)
$$

Jumlah kuadrat deviasi (S), dihitung dengan formula:

$$
\mathrm{S}=\sum_{n}^{1}=1(\mathrm{R} 1-\mathrm{R}) 2
$$

Sehingga diperoleh Kendall's W, yaitu:

$$
\mathrm{W}=\frac{12 s}{m^{2}\left(n^{s}-n\right)}
$$

Jika nilai pengujian $\mathrm{W}$ sebesar $1(\mathrm{~W}=1)$, dapat disimpulkan bahwa penilaian atau pendapat dari para responden memiliki kesepakatan yang sempurna sedangkan ketika nilai W sebesar atau semakin mendekati 0, maka menunjukan adanya ketidaksepakatan antarjawaban responden atau jawaban bervariatif.

\section{HASIL DAN PEMBAHASAN}

\section{Gambaran Umum Pesantren Al-Ittifaq}

Pesantren Al-Ittifaq merupakan pesantren agribisnis yang terletak di kampung Ciburial, Desa Alam Endah, Kecamatan Rancabali, Kabupaten Bandung, Jawa Barat. Pesantren Al- Ittifaq berdiri pada tanggal 1 Februari 1934 (16 Syawal 1302) oleh K.H. Mansyur. Pada awal berdirinya, pesantren AlIttifaq tergolong ke dalam jenis pondok pesantren salafiyah (tradisional/nonsekolah). Pengelolaan pendidikan yang seadanya dan keengganan untuk membuka diri menyebabkan perkembangan Pesantren Al-Ittifaq sangat lamban, bahkan cenderung berjalan di tempat. Hal ini terus berlangsung hingga kepemimpinan H. Rifai pada tahun 1953-1970.

Kemudian pada tahun 1970 hingga saat ini, kepemimpinan Pesantren Al-Ittifaq dipegang oleh K.H. Fuad Affandi. Di bawah kepemimpinannya, Pesantren Al-Ittifaq berhasil berkembang dengan membuka diri terhadap perkembangan dunia. Pada awal masa kepemimpinannya, K.H. Fuad mulai aktif menggerakkan masyarakat sekitar untuk membangun sarana dan prasarana penunjang desa, seperti jalan, masjid, listrik, dan pengairan untuk irigasi. Aspek pendidikan yang sebelumnya 
tradisional saat ini mulai berkembang. Selain pengajian kitab kuning, terdapat pendidikan formal dan pembekalan keahlian agribisnis bagi santrinya. Dari aspek sosial, Pesantren Al-Ittifaq secara rutin mengadakan kegiatan sosial rutin untuk mengedukasi dan menyejahterakan masyarakat. Beberapa di antaranya pengajian rutin mingguan, nikah massal, khitan massal, renovasi masjid, dan umroh gratis untuk santri dan masyarakat yang berprestasi.

Pesantren Al-Ittifaq menggolongkan santri menjadi dua kategori, yaitu santri khalafiyah, dan santri salafiyah. Santri salafiyah merupakan santri yang mempelajari ilmu agama (kitab kuning) yang dipadukan dengan ilmu dan praktik agribisnis secara langsung. Santri salafiyah mayoritas merupakan santri yang kurang mampu, sehingga selama di pesantren santri salafiyah tidak dikenakan biaya, baik biaya pendidikan, asrama dan biaya hidup. Biaya tersebut dipenuhi dari hasil usaha agribisnis yang mereka kelola. Santri salafiyah memiliki sistem pendidikan yang berbeda dengan khalafiyah, yaitu santri dapat masuk ke pesantren tanpa batasan usia dan waktu belajar. Santri salafiyah dinyatakan lulus saat sudah menikah atau dirasa cukup mandiri.

\section{Gambaran Unit Usaha Pesantren Al-Ittifaq}

Pada tahun 1970 K.H. Fuad Affandi selaku pimpinan pondok pesantren Al-Ittifaq memadukan antara kegiatan keagamaan dengan kegiatan unit usaha pesantren di bidang agribisnis. Alasan Pesantren AlIttifaq mendirikan unit usaha pesantren karena hampir 90\% santri Al-Ittifaq saat itu adalah santri kurang mampu, dan pemikiran bahwa tidak mungkin secara keseluruhan lulusan santri Al-Ittifaq menjadi ulama. Santri didorong untuk mandiri dan belajar tauhid sehingga diharapkan mampu mengajarkan ilmu agama yang diimbangi dengan keahlian. Santri dibagi berdasarkan potensi dan minat yang dimiliki, misalnya di kebun, peternakan, koperasi, kantor, dan pemasaran.

Pemilihan agribisnis sebagai unit usaha didasarkan pada beberapa alasan, di antaranya: pertama, inna a'dhamalkasbi azzar'u yaitu pertanian adalah bidang profesi yang utama. Kedua, potensi lahan dan kondisi geografis yang dimiliki Pesantren Al-Ittifaq. Pesantren Al-Ittifaq berada di Desa Alamendah yang terletak di dataran tinggi dengan ketinggian antara 1300-2350 mdpl, menjadi salah satu daerah terdampak letusan Gunung Patuha sehingga memiliki tanah yang subur dan cocok untuk mengembangkan komoditas agribisnis. Ketiga, dalam mengelola pertanian tidak diperlukan pendidikan khusus dan dapat dilakukan semua kalangan. Keempat, untuk memanfaatkan setiap lahan yang ada di sekitar pesantren. Pesantren memiliki prinsip tidak boleh ada sejengkal tanah yang terbengkalai, sehingga pesantren menanami lahannya dengan beberapa jenis tanaman dalam satu lahan agar tidak ada lahan yang terbengkalai. Kelima, pertanian dianggap mampu memberikan kehidupan bagi makhluk hidup yang terlibat di dalamnya, seperti manusia, hewan dan tumbuhan.

Pelaksanaan pengembangan unit usaha Pesantren Al-Ittifaq didasarkan kepada prinsip INPEKBI (Ilahi, Negeri, Pribadi, Ekonomi, Keluarga, Birahi, dan Ilmihi). Ilahi memiliki makna bahwa dalam pengembangan unit usaha pesantren, maka harus diridhoi oleh Allah SWT. Maka dari itu, dalam pelaksanaannya, unit usaha pesantren sesuai dengan prinsip syariah. Negeri memiliki makna bahwa dalam melaksanakan pengembangan unit usaha harus melakukan kerja sama dan kordinasi yang baik dengan pemerintah agar tidak ada pembatas antara pesantren dengan pihak pemerintah. Pribadi memiliki makna bahwa dalam melaksanakan pengembangan unit usaha harus memiliki kepribadian usaha yang mandiri, tidak bergantung pada bantuan dari pihak lain.

Ekonomi memiliki makna bahwa santri yang sudah lulus dari pesantren harus memiliki kemampuan wirausaha untuk mengembangkan perekonomian dan dijadikan contoh bagi masyarakat. Kekeluargaan memiliki makna bahwa tidak ada batas pemisah antara pesantren dengan pihak eksternal Pesantren Al-Ittifaq. Birahi memiliki makna pesantren akan menikahkan santri, kemudian diberikan tugas untuk mengabdi menjadi anggota Dewan Kemakmuran Masjid dan mengelola lahan pertanian. Ilmi memiliki makna pengembangan usaha harus terus dilakukan dengan penguasaan ilmu dan teknologi untuk meningkatkan produksi. 
Pesantren Al-Ittifaq memiliki tiga unit usaha, di antaranya: Koperasi Pondok Pesantren Al-Ittifaq, peternakan Al-Ittifaq, dan PT Al-Ittifaq Agriculture Indonesia. Ketiga unit usaha tersebut saling berkaitan satu sama lain karena Pesantren Al-Ittifaq menerapkan sistem pertanian terpadu (integrated farming system). Pesantren Al-Ittifaq mampu memadukan komponen pertanian, seperti tanaman, hewan dan ikan dalam satu kesatuan yang utuh.

Semua hasil usaha digunakan untuk kegiatan operasional unit usaha, operasional pesantren dan kesejahteraan masyarakat. Hasil unit usaha pesantren mampu memberikan kontribusi terbesar dalam kegiatan operasional pesantren, seperti untuk membayar kebutuhan listrik pesantren, pembangunan fasilitas pesantren, beasiswa santri, dan menunjang kehidupan santri salafiyah. Alokasi dana unit usaha pesantren untuk kesejahteraan masyarakat, di antaranya memberikan beasiswa bagi masyarakat sekitar yang kurang mampu, membangun fasilitas sarana dan prasarana desa, mengadakan kegiatan sosial seperti nikah massal, khitan massal, renovasi masjid, dan umroh gratis untuk umum.

\section{Koperasi Pondok Pesantren Al-Ittifaq}

Koperasi Pondok Pesantren Al Ittifaq (Kopontren ALIF) mulai menjalankan kegiatan koperasi sejak tahun 1970, namun baru menjadi lembaga koperasi resmi pada 6 Juni 1997. Koperasi Pesantren AlIttifaq menaungi kegiatan simpan pinjam dan pemasaran produk pertanian. Anggota koperasi merupakan santri, pengurus pesantren, masyarakat sekitar, lembaga yang menjadi mitra koperasi, dan pedagang pasar di Bandung. Kopontren ALIF menyediakan layanan tabungan dan pembiayaan sesuai dengan prinsip syariah yaitu tanpa dikenakan potongan dan biaya administrasi. Pada awal berdirinya, kegiatan simpan pinjam koperasi sempat mengalami keterpurukan karena banyaknya masyarakat yang tidak mengembalikan pinjamannya tepat waktu. Seiring berjalannya waktu, permasalahan tersebut dapat diatasi dengan pendampingan dan pelatihan keuangan yang dilakukan berbagai pihak.

Kegiatan pemasaran produk pertanian dimulai sejak tahun 1993, namun koperasi baru berhasil menjual sayuran ke supermarket secara mandiri di tahun 1997. Saat ini koperasi mampu memproduksi 134 produk sayur dan buah untuk dijual ke beberapa supermarket, online market, pasar tradisional, rumah sakit, dan rumah makan di Bandung dan Jakarta. Sebesar 70\% produk yang dipasarkan diperoleh dari kelompok tani (poktan) yang tersebar di beberapa daerah, 20\% produk lainnya diperoleh dari lahan pesantren yang dikelola santri, dan $10 \%$ sisanya dari pasar tradisional dan pesantren binaan untuk produk yang tidak dapat dibudidayakan di lingkungan pesantren. Dalam satu tahun, koperasi pesantren Al-Ittifaq memiliki penghasilan rata-rata Rp 6 miliar pertahunnya.

Alur produksi produk pertanian Pesantren Al-Ittifaq mencakup kegiatan budidaya, pencucian, grading, packaging, dan wrapping. Proses budidaya dilakukan dengan menggunakan sistem pola tanam, yaitu setiap hari tanam setiap hari panen untuk menjaga kontinuitas produk. Proses pencucian dilakukan untuk menghilangkan tanah dan residu yang masih menempel di sayuran. Proses grading yaitu pemisahan produk yang sudah bersih menjadi bermacam-macam mutu atas dasar sifat-sifat fisiknya. Berdasarkan kualitasnya, koperasi pesantren Al-Ittifaq membaginya menjadi lima kelas yaitu kelas A, B, C, D, dan E.

Kelas A merupakan produk dengan kualitas tertinggi untuk dipasarkan ke supermarket dan offline store yang bekerja sama dengan koperasi. Kelas B merupakan produk sayur dengan kualitas baik yang dijual untuk dijadikan sayuran olahan ke rumah makan di Bandung. Kelas $\mathrm{C}$ merupakan produk sayur dengan kualitas menengah yang dipasarkan ke beberapa pasar tradisional di Bandung. Kelas D merupakan produk sayur yang dikonsumsi untuk kebutuhan internal pesantren, seperti konsumsi santri, karyawan dan tamu pesantren. Kelas E merupakan produk sayuran dengan kualitas rendah yang diberikan untuk pakan ikan dan hewan ternak. Produk yang sudah melalui proses grading, kemudian masuk proses pengemasan menggunakan menggunakan wadah styrofoam, wadah plastik, atau hanya dilapisi plastik wrap. Terakhir produk Koperasi Al-Ittifaq diberi label produk dengan merek dagang Alif. 


\section{Peternakan Pesantren Al-Ittifaq}

Pesantren Al-Ittifaq mengembangkan usaha peternakan sejak berdirinya pesantren di tahun 1934 . Namun, pada saat itu pengelolaan peternakan masih bersifat tradisional dan dilakukan sebatas sebagai penyaluran hobi sehingga belum ada pemisahan aset antara aset pesantren dengan aset kiai. Kegiatan peternakan yang dilakukan yaitu budidaya sapi milik kiai dan sapi titipan milik masyarakat sekitar dengan akad mudarabah. Ternak yang dititipkan, dirawat oleh santri hingga cukup umur kemudian dijual untuk memenuhi kebutuhan masyarakat sekitar atau internal pesantren saat Idul Adha. Pada tahun 2015, pengelolaan peternakan Al-Ittifaq dilakukan secara mandiri oleh pengurus peternakan dan berada di bawah pengawasan Koperasi Pesantren Al-Ittifaq. Hal tersebut menjadikan aset peternakan terpisah dengan aset kiai ataupun pengurus yayasan. Kegiatan peternakan di Pesantren Al-Ittifaq meliputi kegiatan budidaya, pemasaran, dan pengolahan limbah ternak. Peternakan Al-Ittifaq terdiri dari peternakan domba, peternakan sapi perah dan peternakan sapi potong. Hasil dari produk ternak saat ini dijual secara komersial kepada masyarakat luas dalam bentuk susu, daging mentah, maupun daging olahan yang digunakan untuk keperluan acara keagamaan.

\section{PT Al-Ittifaq Agriculture Indonesia}

PT Al-Ittifaq Agriculture Indonesia merupakan badan usaha yang memfasilitasi kegiatan dari pihak eksternal pesantren seperti penginapan, katering dan travel. PT Al-Ittifaq Agriculture Indonesia bekerja sama dengan yayasan Pesantren dalam mengelola Balai Latihan Kerja Komunitas (BLKK) dan Lembaga Kursus dan Pelatihan (LKP) di bawah pengawasan Kementrian Ketenagakerjaan RI, dan Kementrian Pendidikan dan Kebudayaan RI sebagai fasilitas pelatihan bagi santri dan masyarakat umum agar memiliki keahlian.

PT Al-Ittifaq Agriculture Indonesia bergerak secara mandiri dalam kegiatan operasionalnya. Penghasilan yang didapatkan oleh PT Al-Ittifaq Agriculture Indonesia bersumber dari wadah lembaga kursus, narasumber dalam berbagai kegiatan instansi, fasilitator bagi lembaga atau instansi yang ingin melakukan kunjungan ke pesantren, dan berbagai biaya fasilitas penunjang yang telah disediakan. Alokasi dari penghasilan tersebut dikembalikan untuk kegiatan operasional usaha, kegiatan sosial pesantren, pemberdayaan SDM, pembayaran pajak, dan pembelian sarana penunjang kegiatan PT AlIttifaq Agriculture Indonesia.

\section{Faktor-faktor yang Memengaruhi Kemandirian Ekonomi Pesantren Al-Ittifaq}

Berdasarkan hasil literature review dan wawancara mendalam (in-depth interview) kepada para pakar dan praktisi ekonomi pesantren Al-Ittifaq, faktor-faktor yang memengaruhi kemandirian ekonomi Pesantren Al-Ittifaq terbagi ke dalam empat aspek, yaitu aspek kelembagaan, produksi, stakeholder, dan pasar. Aspek kelembagaan meliputi empat faktor, yaitu faktor entitas unit usaha, sistem informasi akuntansi, kepemimpinan kiai dan pengurus, dan budaya organisasi. Aspek produksi meliputi empat faktor, yaitu faktor sistem informasi produksi, teknologi produksi, ketersediaan SOP produksi, dan sumber daya manusia. Aspek stakeholder meliputi tiga faktor, yaitu faktor permodalan, bimbingan teknis atau pelatihan dan partisipasi masyarakat. Aspek pasar meliputi tiga faktor, yaitu faktor ketersediaan pasar, kepastian pasar dan kemudahan akses pasar. 

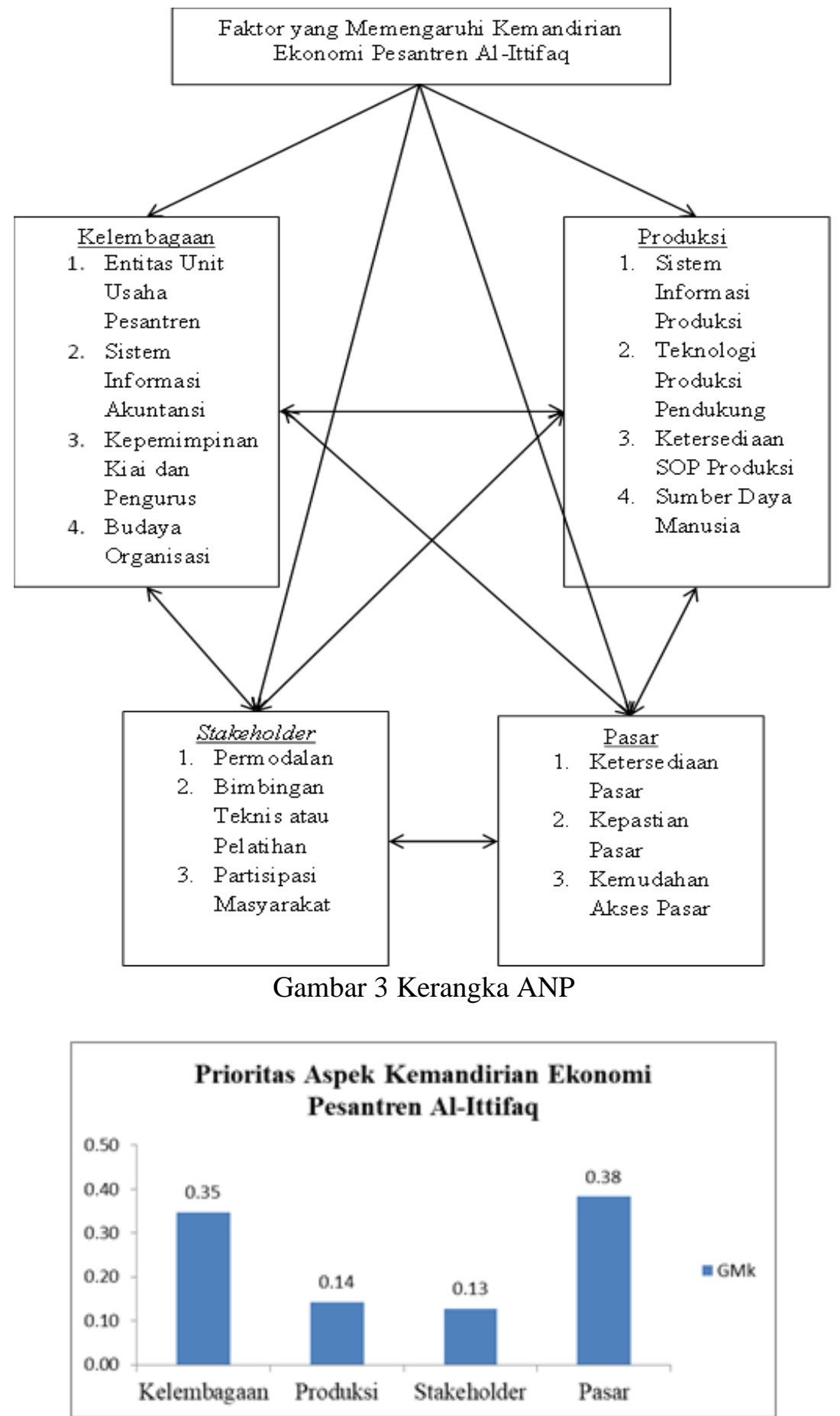

Sumber: Data primer, 2020 (diolah).

Gambar 4 Prioritas aspek kemandirian ekonomi pesantren Al-Ittifaq

Berdasarkan hasil kuantifikasi data menggunakan software Super Decisions, prioritas utama aspek yang memengaruhi kemandirian ekonomi Pesantren Al-Ittifaq adalah faktor ekstenal pasar dengan geometric mean (GMk) sebesar 0.38. Prioritas faktor dapat dilihat pada Gambar 4. Perhitungan rater agreement menghasilkan nilai koefisien Kendall's coefficient of concordance atau W sebesar 0.68 yang menunjukkan bahwa pakar dan praktisi sepakat dalam menentukan urutan prioritas faktor. Nilai prioritas yang cukup besar menunjukan bahwa pakar menilai aspek pemasaran produk memiliki peran yang paling berpengaruh dalam menunjang kemandirian ekonomi Pesantren Al-Ittifaq. 
Aspek kelembagaan menjadi aspek kedua yang memengaruhi kemandirian ekonomi Pesantren AlIttifaq dengan GMk sebesar 0.35. Menurut pakar, pihak internal pesantren berperan penting dalam pengelolaan unit usaha pesantren dan pemberdayaan ekonomi masyarakat. Keberhasilan Pesantren Al-Ittifaq dalam proses produksi hingga pemasaran produk tidak lepas dari kebijakan dan kontribusi lembaga internal pesantren dengan masyarakat sekitar.

Prioritas ketiga faktor yang memengaruhi kemandirian ekonomi Pesantren Al-Ittifaq adalah aspek produksi dengan GMk sebesar 0.14. Menurut pakar, kemandirian ekonomi pesantren Al-Ittifaq saat ini ditunjang oleh peran kegiatan produksi yang efektif. Produktivitas yang dihasilkan oleh kegiatan produksi akan memengaruhi kinerja dan profit yang didapat unit usaha Pesantren Al-Ittifaq.

Aspek stakeholder menjadi aspek terkakhir yang memengaruhi kemandirian ekonomi Pesantren Al-Ittifaq dengan GMk sebesar 0.13. Menurut pakar, sebagai sebuah lembaga pendidikan yang memiliki unit usaha, pesantren Al-Ittifaq tidak lepas dari peran stakeholder eksternal pesantren. Stakeholder eksternal berperan dalam perizinan operasional unit usaha pesantren, memberikan bimbingan dan pendampingan usaha dan pengembangan pengelolaan unit usaha Pesantren Al-Ittifaq.

\section{Aspek kelembagaan}

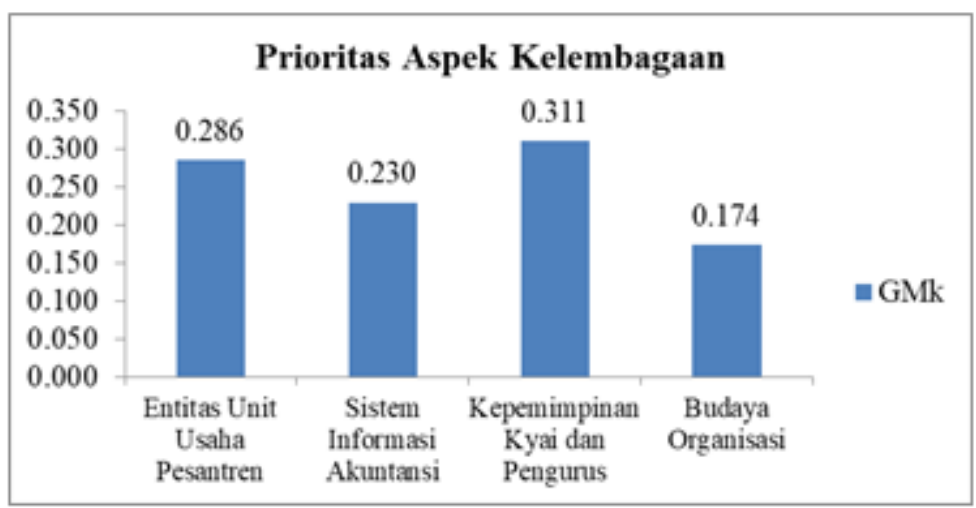

Sumber: Data primer, 2020 (diolah).

Gambar 5 Prioritas aspek kelembagaan

Prioritas utama pada aspek kelembagaan adalah faktor kepemimpinan kiai dan pengurus dengan geometric mean (GMk) sebesar 0.311 seperti yang ditunjukan pada Gambar 5. Hasil perhitungan rater agreement pada aspek ini menunjukkan nilai $\mathrm{W}$ sebesar 0.52 yang berarti para pakar sepakat dengan urutan prioritas faktor. Hasil ini sejalan dengan penelitian Yasin (2001) yang menyatakan bahwa keberhasilan kegiatan usaha pengembangan organisasi sebagian besar ditentukan oleh kualitas kepemimpinannya. Pada Pesantren Al-Ittifaq, K.H. Fuad memegang peran strategis dalam memimpin pesantren. K.H. Fuad dianggap sebagai sosok yang paling berjasa dalam pengembangan kegiatan perekonomian Pesantren Al-Ittifaq hingga berhasil seperti saat ini. Saat ini, kiai menjabat sebagai Dewan Pengawas Pesantren, sedangkan pengelolaan unit usaha diserahkan kepada masing-masing pengurus unit usaha pesantren. Kerja sama yang baik antara kiai dan pengurus mampu mengembangkan unit usaha Pesantren Al-Ittifaq yang sebelumnya tradisional menjadi model percontohan unit usaha pesantren yang modern.

Faktor entitas unit usaha menjadi prioritas kedua dengan GMk sebesar 0.286. Menurut Adizes (1988), organisasi bisnis akan bisa hidup saat organisasi bisnis memiliki keabsahan secara hukum (memiliki legalitas hukum). Berdasarkan wawancara dengan pakar, faktor entitas unit usaha penting dilakukan untuk mencegah bercampurnya kepemilikan aset kiai dengan aset unit usaha pesantren. Keberadaan koperasi pesantren sebagai unit usaha yang memiliki legalitas hukum menjadikannya sebagai entitas terpisah dari yayasan pesantren sehingga segala aset dan liabilitas dari pondok pesantren harus dapat dibedakan dengan aset dan liabilitas dari entitas lainnya baik yayasan pesantren maupun kiai. 
Prioritas ketiga adalah faktor sistem informasi akuntansi dengan GMk sebesar 0.23. Hal ini sejalan dengan penelitian Theng dan Boon (1996) bahwa salah satu faktor utama yang menyebabkan kegagalan UKM dalam mengembangkan usaha adalah karena kelemahan sisi manajemen yang dipengaruhi oleh ketidakmampuan UKM dalam menyediakan sistem informasi akuntansi. Pesantren Al-Ittifaq berusaha menjalankan pencatatan keuangan sesuai dengan pedoman akuntansi pesantren yang diterbitkan oleh Bank Indonesia. Prinsip transparansi dalam pembuatan laporan keuangan yang standar dipahami secara formal akan memudahkan akses Pesantren Al-Ittifaq ke pasar.

Faktor budaya organisasi menjadi prioritas terakhir dengan GMk sebesar 0.174. Berdasarkan hasil wawancara, salah satu budaya organisasi yang diterapkan Pesantren Al-Ittifaq adalah "sholat di awal waktu dan berjamaah di masjid" menjadi faktor yang meningkatkan kualitas dan produktivitas sumber daya manusia pesantren. Budaya ini mulai diterapkan pada tahun 1993 oleh K.H. Fuad dan dianggap sebagai titik balik pertumbuhan unit usaha pesantren. Sebelum budaya ini diterapkan, Pesantren AlIttifaq mengalami keterpurukan karena rendahnya kualitas dan kuantitas produksi. Setelah budaya ini diterapkan secara massal, jumlah produksi dan kualitas produk pesantren berangsur meningkat. Hasil ini sejalan dengan penelitian Thoyib (2005) yang menyatakan bahwa kinerja yang tinggi pada individu dalam organisasi dapat dicapai dengan budaya organisasi yang baik.

\section{Aspek produksi}

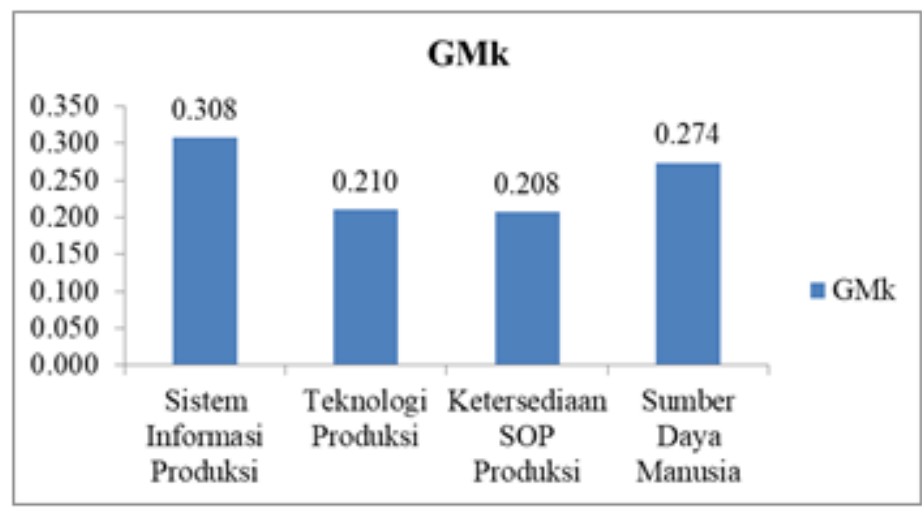

Sumber: Data primer, 2020 (diolah).

Gambar 6 Prioritas aspek produksi

Prioritas utama pada aspek produksi adalah faktor sistem informasi produksi dengan geometric mean (GMk) sebesar 0.308 seperti yang ditunjukan pada Gambar 6. Hasil perhitungan rater agreement pada aspek ini menunjukkan nilai $\mathrm{W}$ sebesar 0.40 yang berarti para pakar memiliki pendapat yang sepakat dengan urutan prioritas faktor. Menurut Bodnar dan Hopwood (2000), sistem informasi produksi adalah sistem informasi manajemen yang digunakan untuk fungsi produksi.

Berdasarkan hasil wawancara, sistem informasi produksi berguna untuk menghubungkan informasi produksi dari pihak internal dan eksternal Koperasi Pesantren Al-Ittifaq untuk merencanakan, monitoring dan mengontrol proses produksi agar lebih efisien. Pemesanan dilakukan via email, kemudian direkap oleh bagian administrasi, kemudian dibagi berdasarkan jenis dan kuantitas produk sayuran yang dipesan ke petani melalui grup WhatsApp. Terakhir, petani menyetorkan sayuran ke koperasi sesuai dengan pesanan. Metode tersebut dianggap efisien karena pada prosesnya tidak ada produk yang terbuang.

Sumber daya manusia menjadi faktor kedua dengan GMk sebesar 0.274. Hal ini sejalan dengan penelitian (Munizu, 2010), bahwa aspek sumber daya manusia berpengaruh positif dan signifikan memengaruhi kinerja usaha mikro dan kecil di Sulawesi Selatan. Dalam proses produksinya, unit usaha Pesantren Al-Ittifaq merekrut sumber daya manusia baik dari internal pesantren (santri 
salafiyah) dan eksternal pesantren (masyarakat umum). Tujuannya adalah untuk memberikan keahlian wirausaha pada santri salafiyah dan meningkatkan perekonomian masyarakat sekitar pesantren.

Prioritas ketiga adalah teknologi produksi dengan GMk sebesar 0.210. Hal ini sejalan dengan penelitian Munizu (2010) bahwa teknologi menjadi salah satu faktor yang memengaruhi kinerja UKM. Perkembangan penggunaan teknologi dirasakan hampir di seluruh aspek operasional unit usaha pesantren. Pada proses budidaya, petani yang sebelumnya menggunakan metode tradisional untuk membuka lahan, kini sudah menggunakan teknologi traktor agar lebih efisien. Penggunaan teknologi untuk proses produksi meliputi proses pencucian sayur yang menggunakan mesin otomatis, proses pengemasan menggunakan wadah styrofoam, atau wadah plastik sesuai dengan standar keamanan. Proses labelling yang meliputi merk dagang, bahan baku, tanggal kadaluarsa, dan legalitas. Selain itu, penggunaan teknologi handphone, komputer dan aplikasi dropbox memudahkan bagian administrasi dalam melakukan komunikasi, pencatatan dan penyimpanan data yang terintegrasi.

Ketersediaan Standar Operasional Prosedur (SOP) produksi menjadi prioritas terakhir dengan GMk sebesar 0.21. Menurut Bank Indonesia (2016), lembaga pesantren sebaiknya memiliki standar operasi yang efektif untuk diimplementasikan sehingga setiap kegiatan produksi maupun pelaporannya dapat dilakukan dengan efektif. Saat ini Pesantren Al-Ittifaq sudah menerapkan SOP produksi yang meliputi proses penanaman, pemanenan, pengemasan, hingga pemasaran produk. Proses budi daya dan pemanenan dilakukan setiap hari untuk menjaga kontinuitas produk. Grading dan pengemasan produk sesuai standar penting dilakukan untuk mencegah retur produk. Kegiatan pemasaran dilakukan dua kali sehari untuk menjaga kesegaran produk. SOP produksi koperasi menggunakan prinsip bertani dan berdagang untuk mengaji, sehingga kegiatan produksi bukan menjadi halangan dalam beribadah.

\section{Aspek stakeholder}

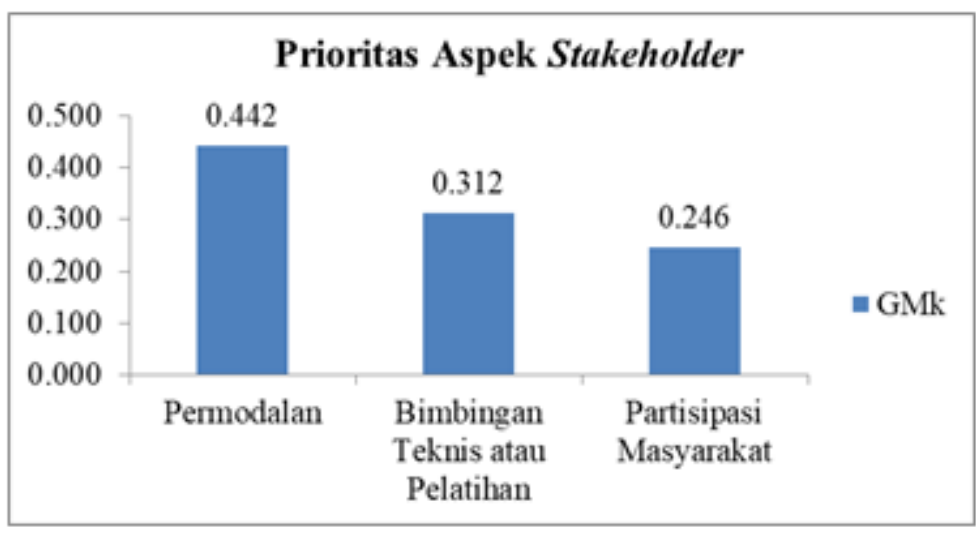

Sumber: Data primer, 2020 (diolah).

\section{Gambar 7 Prioritas aspek stakeholder}

Prioritas utama pada aspek stakeholder adalah faktor permodalan dengan geometric mean (GMk) sebesar 0.442 seperti yang ditunjukan pada Gambar 7. Hasil perhitungan rater agreement pada aspek ini menunjukkan nilai W sebesar 0.51 yang berarti para pakar sepakat dengan urutan prioritas faktor. Selama ini permodalan dari pihak eksternal turut menunjang operasional dan pembangunan Pesantren Al-Ittifaq. Hal ini sejalan dengan kajian Bank Indonesia (2019), bahwa akses ke lembaga keuangan menjadi tantangan dalam pengembangan ekonomi pesantren. Secara tidak langsung permodalan dari pihak eksternal turut menunjang operasional ekonomi Pesantren Al-Ittifaq. Beberapa permodalan yang pernah diberikan kepada Pesantren Al-Ittifaq di antaranya mesin pencuci sayur, pembangunan green house dan pipanisasi dari Bank Indonesia, pembiayaan kredit usaha rakyat dan mobil operasional dari PT Bank Negara Indonesia Tbk, dana untuk memaksimalkan peran gedung BLKK, dan bantuan pembiayaan usaha dari berbagai instansi lainnya. 
Faktor bimbingan teknis atau pelatihan menjadi prioritas kedua dengan GMk sebesar 0.312 . Bimbingan teknis atau pelatihan diberikan untuk meningkatkan kapabilitas sumber daya manusia unit usaha Pesantren Al-Ittifaq dalam segala bidang. Bank Indonesia (2015), menyatakan bahwa meskipun sumber daya manusia dalam penguasaan bidang keagamaan sangat mumpuni, namun dalam meningkatkan eksistensi dan peran pesantren di kehidupan masyarakat sangat diperlukan. Pemberian bimbingan teknis atau pelatihan juga dapat meningkatkan produktivitas produksi dan pemberdayaan ekonomi masyarakat sekitar.

Bimbingan teknis atau pelatihan yang pernah diberikan ke Pesantren Al-Ittifaq di antaranya, pelatihan manajemen agribisnis dan pemasaran produk oleh PUM Netherlands Senior Experts, pelatihan untuk pemberdayaan varietas wortel kuroda dan pemasarannya oleh Japan International Cooperation Agency (JICA), bimbingan teknis dan pelatihan pemberdayaan ternak domba dalam rangka Program Domba Nasional (Prodombas) yang diselenggarakan oleh Majelis Ulama Indonesia (MUI), pelatihan tentang koperasi dan administrasi bagi pengurus koperasi yang dilakukan oleh Balai Latih Koperasi dan Bank Indonesia. Selain mendapatkan bimbingan teknis dan pelatihan, Pesantren Al-Ittifaq juga secara aktif memberikan bimbingan teknis dan pelatihan kepada pesantren bimbingan maupun masyarakat umum terkait pengelolaan unit usaha agribisnis.

Prioritas terakhir adalah faktor partisipasi masyarakat GMk sebesar 0.246. Menurut pakar partisipasi masyarakat memegang peran penting dalam perkembangan ekonomi pesantren Al-Ittifaq. Masyarakat berperan sebagai salah satu pemegang modal dalam koperasi pesantren, masyarakat kelompok tani berperan menjadi supplier terbesar produk pertanian yang dipasarkan oleh koperasi pesantren dan masyarakat sebagai sumber daya manusia yang mengelola unit usaha pesantren. Hubungan dua arah antara Pesantren Al-Ittifaq dengan masyarakat dapat terlihat dari masyarakat yang mendapatkan manfaat lapangan pekerjaan dan pengetahuan agama yang diajarkan pesantren melalui kajian rutin. Bagi pesantren, partisipasi masyarakat turut membantu menyukseskan berbagai agenda pesantren, baik di bidang pendidikan, sosial, maupun ekonomi. Hal ini sejalan dengan penelitian Syarbani (2012) bahwa rendahnya partisipasi santri menjadi salah satu faktor penyebab rendahnya kinerja koperasi pondok pesantren di Kota Semarang.

\section{Aspek pasar}

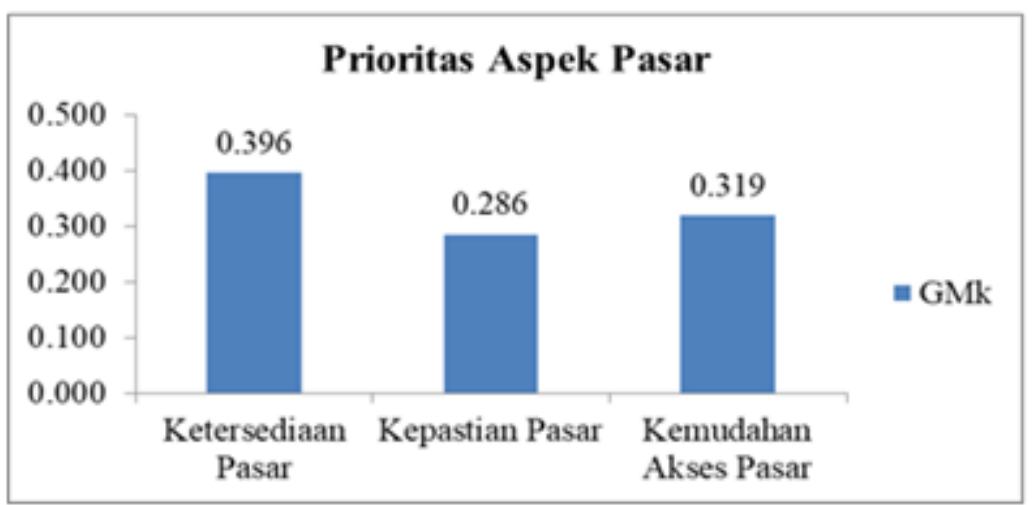

Sumber: Data primer, 2020 (diolah).

Gambar 8 Prioritas aspek pasar

Prioritas utama pada aspek pasar adalah faktor ketersediaan pasar dengan geometric mean (GMk) sebesar 0.396 seperti yang ditunjukan pada Gambar 8 . Hasil perhitungan rater agreement pada aspek ini menunjukkan nilai $\mathrm{W}$ sebesar 0.43 yang berarti para pakar sepakat dalam menentukan prioritas faktor. Sebelum memutuskan untuk mendirikan unit usaha agribisnis, K.H. Fuad selaku pemimpin Pesantren Al-Ittifaq terlebih dahulu membaca dan memahami setiap potensi yang dimiliki pesantren, termasuk potensi lahan, potensi ketersediaan pasar untuk produk pertanian, kemudian menyesuaikan komoditas yang akan ditanam dengan kondisi lahan pesantren. Hal ini sejalan dengan penelitian yang 
dilakukan oleh Munizu (2010) bahwa ketersediaan pasar menjadi salah satu faktor prioritas dalam menentukan kinerja usaha kecil dan menengah pengolah produk berbasis pangan. Dalam penelitian tersebut, indikator ketersediaan pasar memiliki bobot yang paling tinggi dalam menunjang faktor internal.

Sejalan dengan penelitian Rasmikayati (2021), kemudahan akses memiliki pengaruh yang signifikan terhadap proses penjualan dan variabel pendukung lainnya. Kemudahan akses pasar juga menjadi prioritas kedua dengan geometric mean (GMk) sebesar 0.319. Setelah menemukan komoditas yang sesuai, K.H. Fuad mendapatkan akses untuk menjual sayurannya ke supermarket melalui perantara Koperasi Unit Desa (KUD) Pasir Jambu hingga berhasil bekerja sama dengan supermarket secara mandiri. Melalui jaringan dan kualitas produk yang dimiliki saat ini, Koperasi Pesantren Al-Ittifaq mampu mengakses pasar lebih mudah.

Prioritas terakhir adalah faktor kepastian pasar. Penelitian Pratiwi et al. (2020) menyimpulkan bahwa faktor kepastian pasar menjadi alasan petani mememilih platform crowdfunding sebagai salah satu pendanaan alternatif. Faktor kepastian pasar dengan GMk sebesar 0.286. Menurut pakar, setelah melihat ketersediaan pasar, maka langkah selanjutnya adalah melihat kepastian pasar melalui segmentasi produk yang diproduksi. Kemampuan Koperasi Pesantren Al-Ittifaq dalam menjaga kestabilan kualitas dan kuantitas produk telah menciptakan rasa percaya konsumen terhadap produk pesantren sehingga Pesantren Al-Ittifaq memiliki bargaining position dan memperoleh kepastian pasar untuk masing-masing kelas produknya.

\section{SIMPULAN}

Pesantren Al-Ittifaq memiliki tiga unit usaha bisnis yaitu Koperasi Pondok Pesantren Al-Ittifaq, peternakan Al-Ittifaq, dan PT Al-Ittifaq Agriculture Indonesia. Ketiga unit usaha tersebut dikelola oleh santri dan masyarakat sekitar pesantren. Seluruh hasil usaha digunakan untuk kegiatan operasional unit usaha, operasional pesantren dan kesejahteraan masyarakat. Keberhasilan Pesantren Al-Ittifaq dalam mengembangkan unit usaha agribisnis menjadikannya sebagai salah satu model pesantren yang mampu mencapai kemandirian ekonomi pesantren.

Faktor-faktor yang memengaruhi kemandirian ekonomi Pesantren Al-Ittifaq terbagi menjadi empat aspek yaitu aspek pasar, aspek kelembagaan, aspek produksi, dan aspek stakeholder. Pakar dan praktisi cenderung bersepakat bahwa prioritas utama aspek yang memengaruhi kemandirian ekonomi Pesantren Al-Ittifaq adalah aspek pasar. Hasil prioritas faktor secara keseluruhan menunjukkan bahwa empat faktor yang paling memengaruhi aspek kemandirian ekonomi Pesantren Al-Ittifaq adalah kepemimpinan kiai dan pengurus, sistem informasi produksi, permodalan, dan ketersediaan pasar.

\section{DAFTAR PUSTAKA}

Adizes, I. (1988). Corporate Lifecycles: How and Why Corporations Grow and Die and What to do About It. New Jersey (US), Prentice Hall.

Ascarya. (2005). Analytic Network Process (ANP) Pendekatan Baru Studi Kualitatif. Jakarta (ID), Seminar Internasional Program Magister Akuntansi Fakultas Ekonomi; 2005 Januari 27.

Ascarya. (2011). The Development of Islamic Financial System in Indonesia and the Way Forward. Occasional Papers No. OP/10 /02, 2010.

[BI] Bank Indonesia. (2015). Identifikasi Key Success Factor Lembaga Pesantren. Jakarta (ID): Bank Indonesia.

[BI] Bank Indonesia. (2019). Penyusunan Kajian Model Holding Pesantren. Jakarta (ID), Bank Indonesia.

[BI dan Kemenag] Bank Indonesia dan Kementerian Agama Republik Indonesia. (2016). Roadmap Pengembangan Kemandirian Ekonomi Pesantren. Jakarta (ID): Bank Indonesia. 
Bodnar, G.H. \& Hopwood, W.S. (2010). Accounting Information System. Yogyakarta (ID), ANDI.

Firmansyah, I., Dermawan, W. D., Munawar, A. H., \& Rahmani, D. A. (2021). Meningkatkan daya saing UMKM di era new normal melalui pendekatan Analytic Network Process (ANP). Jurnal Ekonomi Indonesia, 10(2), 173-187.

Fitri, F. A., Harta, G., \& Nur, N. (2020). Penentuan alternatif pilihan strategi mitigasi riisiko kecelakaan kerja dengan metode ANP di PT XYZ. Jurnal Rekayasa dan Optimasi Sistem Industri, 2(2), 44-50.

Isti'anah, A., dan Sutikno, S. (2018). Memaknai peran pondok pesantren An-Nuqayah Gulukguluk dalam pengentasan kemiskinan di pedesaan. FALAH: Jurnal Ekonomi Syariah, 3(1), 97. https://doi.org/10.22219/jes.v3i1.5982.

[Kemenag] Kementrian Agama. (2019). Pangkalan Data Pendidikan Pondok Pesantren. Jakarta (ID), PDPP.

[Kemenkop] Kementerian Koperasi dan Usaha Kecil dan Menengah Republik Indonesia (2010). Undang-Undang Republik Indonesia Nomor 20 Tahun 2008 tentang Usaha Mikro, Kecil, dan Menengah. Jakarta (ID), Kemenkop.

[Kemenkop] Kementerian Koperasi dan Usaha Kecil dan Menengah (2017). Perkembangan Data Usaha Mikro, Kecil, dan Menengah Tahun 2015, Unpublished.

Melis, M. (2019). Pengelolaan sumber daya insani dalam memasarkan produk dan jasa lembaga keuangan syariah. Islamic Banking: Jurnal Pemikiran dan Pengembangan Perbankan Syariah, 5(1), 1-10.

Munizu, M. (2010). Pengaruh faktor-faktor eksternal dan internal terhadap kinerja Usaha Mikro dan Kecil (UMK) di Sulawesi Selatan. Jurnal Manajemen dan Kewirausahaan, 12(1), 33-41. https://doi.org/10.9744/jmk.12.1.pp.33-4.

Pratiwi, P. Y., Yanuarti, I. \& Prihanto, W. (2020). Faktor-faktor yang memengaruhi petani dalam memilih platform crowdfunding (studi kasus pada petani hortikultura di Desa Sumberejo, Magelang). Ultima Management: Jurnal Ilmu Manajemen, 12(1), 83-103. https://doi.org/10.31937/manajemen.v12i1.1578.

Rahmadani, S. \& Makmur. (2019). Analisis studi kelayakan bisnis pada pengembangan UMKM usaha tahu dan tempe karya mandiri ditinjau dari aspek produksi, aspek pemasaran dan aspek keuangan. Hirarki: Jurnal Ilmiah Manajemen dan Bisnis, 1(1), 76-83.

Ranis, G., \& Stewart, F. (2005). Dynamic links between the economy and human development. 050(8), 1-16.

Rasmikayati, E. (2021). Akses pasar mangga dan faktor yang memengaruhinya (studi komparatif antara Kecamatan Greged dan Japara). Jurnal Pertanian Agros, 2(2), 1-7.

Romindo, R., \& Jamaludin, J. (2019). Sistem pendukung keputusan menggunakan metode ANP untuk pemilihan toko daring terbaik di Politeknik Ganesha. REMIK (Riset Dan E-Jurnal Manajemen Informatika Komputer), 4(1), 83. https://doi.org/10.33395/remik.v4i1.10231.

Ryandono, M. N. H. (2018). Peran pondok pesantren dalam pemberdayaan sosial ekonomi di Jawa Timur pada abad ke-20. Mozaik Humaniora, 18(2), 189-204.

Sudarmo, F. (2021). Historiografi pesantren di Indonesia. Historia Madania: Jurnal Ilmu Sejarah, 2(2), 65-80. http://journal.uinsgd.ac.id/index.php/historia/article/view/12369.

Suharto, S. \& Fasa, M. I. (2018). Model pengembangan manajemen bisnis Pondok Modern Darussalam Gontor Ponorogo. Indonesia. Li Falah: Jurnal Studi Ekonomi dan Bisnis Islam, 3(2), 92-110.

Supriyanto, E. E. (2020). Kontribusi pendidikan pesantren bagi pendidikan karakter di Indonesia. Jurnal Pendidikan Nusantara, 1(1), 13-26.

Suryawati, C. (2005). Memahami kemiskinan secara multidimensional. Jurnal Manajemen Pelayanan Kesehatan, 8(03).

Syarbani, H. (2012). Analisis pengaruh partisipasi santri komitmen dan kemampuan berinovasi terhadap kinerja koperasi pondok pesantren di Kota Semarang. Economica: Jurnal Ekonomi Islam, 2(2), 27-42. https://doi.org/10.21580/economica.2012.2.2.848.

Theng, L. G. \& Boon, J. L. W. (1996). An explanatory study of factors affecting the failure of local small and medium entrprises. Asia Pasific Journal of Management, 13(2), 47-61. 
Thoyib A. (2005). Hubungan kepemimpinan, budaya, strategi, dan kinerja: pendekatan konsep. Jurnal Manajemen dan Kewirausahaan, 7(1): 60-73.

Umar, Z., Syawalina, C. F. \& Khairunnisa, K. (2018). Pengaruh akuntabilitas dan transparansi pengelolaan keuangan daerah terhadap kinerja instansi inspektorat Aceh. Kolegial, 6(2), 136148.

Yaqin, A., Lutfillah, L., \& Muhtadin, R. (2021). Strategi membangun ekonomi pesantren melalui sentralisasi kebutuhan fashion pada industri konveksi pondok pesantren Nurul Jadid. Ekonomica Sharia: Jurnal Pemikiran dan Pengembangan Ekonomi Syariah, 7(1), 1-16.

Yasin A. (2001). Kepemimpinan dalam pengembangan organisasi. Jurnal Lintasan Ekonomi Fakultas Ekonomi Universitas Brawijaya Malang, 18(1). 